\title{
On-farm Evaluation and Demonstration of Improved Banana (Musa spp) Technologies under Small-scale Irrigation Schemes of Selected Lowland Districts of Bale Zone, South-eastern Ethiopia
}

\author{
Tilahun Cibsa $^{2 *} \quad$ Negash Bedaso $^{1} \quad$ Chala Chimdessa $^{1} \quad$ Eshetu Ararso $^{2} \quad$ Ayalew Sida $^{1}$ \\ 1.Oromia Agricultural Research Institute, Sinana Agricultural Research Center; PO. Box: 208; Bale-Robe, \\ Ethiopia \\ 2.Oromia Agricultural Research Institute, P.O. Box: 81265; Addis Ababa/Finfinne, Ethiopia
}

\begin{abstract}
On-farm evaluation and demonstration of improved banana technology were carried out under small-scale irrigation scheme in selected lowland districts of Bale Zone. FRG approach was employed and two FRGs in every selected scheme were established with 20 members each. The evaluation and demonstration was implemented on four farmers in each scheme and a total of sixteen (16) farmers were used. Each farmer's field was considered as replication of the trial. Hence; a total of four improved banana varieties namely Giant Cavendish, Dwarf Cavendish, Poyo and Grand Nain were evaluated. From the study result; there were significant differences between mean yield and yield components of banana varieties. The highest number of finger per bunch (142) was recorded for Giant Cavendish followed by Dwarf Cavendish (141) and then Grand Nain (135) varieties whereas the minimum number of finger per bunch (101) was recorded on Poyo variety. On the other hand, the average length of randomly sampled fingers showed that the longest finger $(16.54 \mathrm{~cm})$ was obtained from Giant Cavendish variety whereas the shortest finger length $(10.36 \mathrm{~cm})$ was recorded for Poyo variety. The average yield of banana has also determined for its variation between verities and there was significant $(\mathrm{p}<0.05)$ difference among the mean yield of varieties. Accordingly, maximum yield was recorded from Dwarf Cavendish $\left(17.66\right.$ ton ha $\left.{ }^{-1}\right)$ followed by Giant Cavendish (16.73 ton ha $\left.{ }^{-1}\right)$ and Grand Nain (15.49 tonha $\left.{ }^{-1}\right)$ whereas the lowest yield was obtained from Poyo $\left(10.42\right.$ ton $\left.^{-1}\right)$ variety. Dwarf Cavendish, Giant Cavendish and Grand Nain banana varieties has recorded $40.99 \%, 37.66 \%$ and $32.73 \%$ yield advantage over Poyo variety respectively. In addition, farmer's preferences towards the varieties were collected through supervision and by organizing mini field day. From farmer's feedback during demonstration; Grand Nain banana variety was ranked as $1^{\text {st }}$ selection by the farmers on the bases of market preference, sweetness, medium fruit size and average good yield compared to other varieties. Moreover, Dwarf Cavendish and Giant Cavendish banana varieties were evaluated and ranked as $2^{\text {nd }}$ and $3^{\text {rd }}$ selection by the farmers compare to poyo varieties on the bases of market preference, fruit size and fruit sweetness. Hence; by combining informal research by farmers with formal on-farm testing; Grand Nain, Dwarf Cavendish and Giant Cavendish banana varieties were selected and recommended for further scaling-up in the test area and similar condition under irrigation production system.
\end{abstract}

Keywords: Dwarf Cavendish, Giant Cavendish, Grand Nain, Poyo and FRG

DOI: $10.7176 /$ CER/13-5-02

Publication date:August $31^{\text {st }} 2021$

\section{Introduction}

Bananas and plantains (Musa spp.) rank sixth on the list of staple crops in the world (FAO, 2017). Dessert banana in particular is a commercially important crop in the global trade, both by volume and value, as a leading fruit (Salvador al., 2007). In 2010, world commerce in banana was valued at US 8.05 billion and the total world production of banana is about 106,541,709.00 tons (FAOSTAT, 2012). For many African, Asian and Latin American countries, banana is used as food security crop as well one of the most important crops for foreign exchange earnings (FAOSTAT, 2012). Moreover, banana is considered an important food, because of its chemical composition and high content of vitamins and minerals, particularly potassium (Silva et al., 2002). The pseudostems and leaves are commonly used as mulch in plantations, livestock feed and as wrapping material (Karamura, 1993). Dried leaf bases are extensively used as roofing material for houses, to weave ropes for tethering goats and sheep, and for mattress making (Karamura, 1993; Kamira et al., 2015).

Dessert banana is also the major fruit crop that is most widely grown and consumed in Ethiopia. It is cultivated in several parts where the growing conditions are favorable. Especially in the south and southwestern parts of the country, it is of great socioeconomic importance contributing significantly to the overall wellbeing of the rural communities including food security, income generation and job creation. Nowadays in Ethiopia, banana is produced throughout the country wherever there is adequate rainfall or irrigation practice. From survey conducted during the 2010/2011 production season, about 31,885.86 hectares of land has been covered with banana and the estimated annual production was about 270,571.516 tones in Ethiopia (CSA. 2011). About 3.94 tone/ha of banana were produced in 2015/16 cropping season in the country (CSA, 2016). Banana in Ethiopia covers about 
$59.64 \%(53,956.16$ hectares $)$ of the total fruit area, about $68.00 \%(478,251.04$ tones $)$ of the total fruits produced, and about $38.30 \%(2,574,035)$ of the total fruit producing farmers (CSA, 2014).

In Bale Zone, banana grows on farmers' field both under rain fed and irrigation as means of food consumption and income generation activities. However, most of banana produced in the area were local cultivar which is low yielder, susceptible to disease and therefore less income from banana. Improved and high yielding varieties of banana have been developed by Ethiopia research institute to improve farmers' productivities and income by enabling them adopt high yielding, adaptable and disease resistant varieties. As a result few cultivars such as Dwarf Cavendish, Poyo, Giant Cavendish, and Garand Nain improved varieties were recommended for production (EARO, 1999).

Sinana Agricultural Research Center has so far evaluated some varieties of banana in lowland areas of Bale Zone for its adaptability and had recommended four promising top varieties for the end users. However, the adaptation was not seen under farmers' management condition. Therefore, it is important to evaluate, demonstrate and popularize these varieties under farmers' condition with irrigation practices.

Banana is among perennial crop which need sufficient moisture throughout the year. Irrigation ensures enough moisture essential for banana growth. It provides insurance against short duration drought and cools the soil and atmosphere to provide a suitable surrounding. Hence for the farmers of Harana-Buluk, Mada-wolabu and Bebere District wherever there is irrigation opportunity; engaging in banana production is an advantage, both for consumption and income generation. This study was aimed to popularize improved technologies of banana and enable farmers to evaluate and select well performed banana varieties for their localities under irrigation through enhancing the skill and knowledge of farmers in banana production and management using irrigation water.

\section{Materials and Methods}

\subsection{Description of the Study Area}

The study was conducted in the selected small scale Irrigation scheme of Bale lowland, Oromiya National Regional State, Southeast Ethiopia (Figure 1). The schemes are Gindba-Godjo,Gobaya-Bishan qallo, Haya-Oda and Harakorre. Gondba-Godjo irrigation scheme is located in Harena-Bulk district at distance of, $144 \mathrm{~km}$ and $574 \mathrm{~km}$ from Robe (Zonal town) and Addis-Ababa respectively. The rainfall pattern is bimodal with mean annual rainfall about $630 \mathrm{~mm}$ and mean annual temperature ranges between $26-40^{\circ} \mathrm{C}$. Haya-Oda is located in Dallomana district and the rainfall pattern is bimodal (March - June and September - October) with mean annual rainfall about $610 \mathrm{~mm}$ and mean annual temperature ranges between $26-42^{\circ} \mathrm{C}$.

Gobaya-Bishanqallo irrigation scheme is located at Berbere district about $526 \mathrm{~km}$ southeast of Addis Ababa. The mean annual temperature is about $20.0^{\circ} \mathrm{C}$ and the mean annual minimum and maximum temperatures are $8.9^{\circ} \mathrm{C}$ and $30.44^{\circ} \mathrm{C}$ respectively. There is a slight difference in the temperature throughout the year. The hottest month is February with maximum temperature record $30.44^{\circ} \mathrm{C}$ and the coldest month is December with minimum temperature of $8.91{ }^{\circ} \mathrm{C}$. The mean annual rainfall of the study area is $710 \mathrm{~mm}$. It is characterized by bimodal rainfall with the main rainy season occurring early March through May and the short rain late August through November. Hora-kore irrigation scheme is located in Madawalabu district. The rainfall pattern is bimodal (March - June and September - October) with mean annual rainfall about $600 \mathrm{~mm}$ and mean annual temperature ranges between 2642 oC.

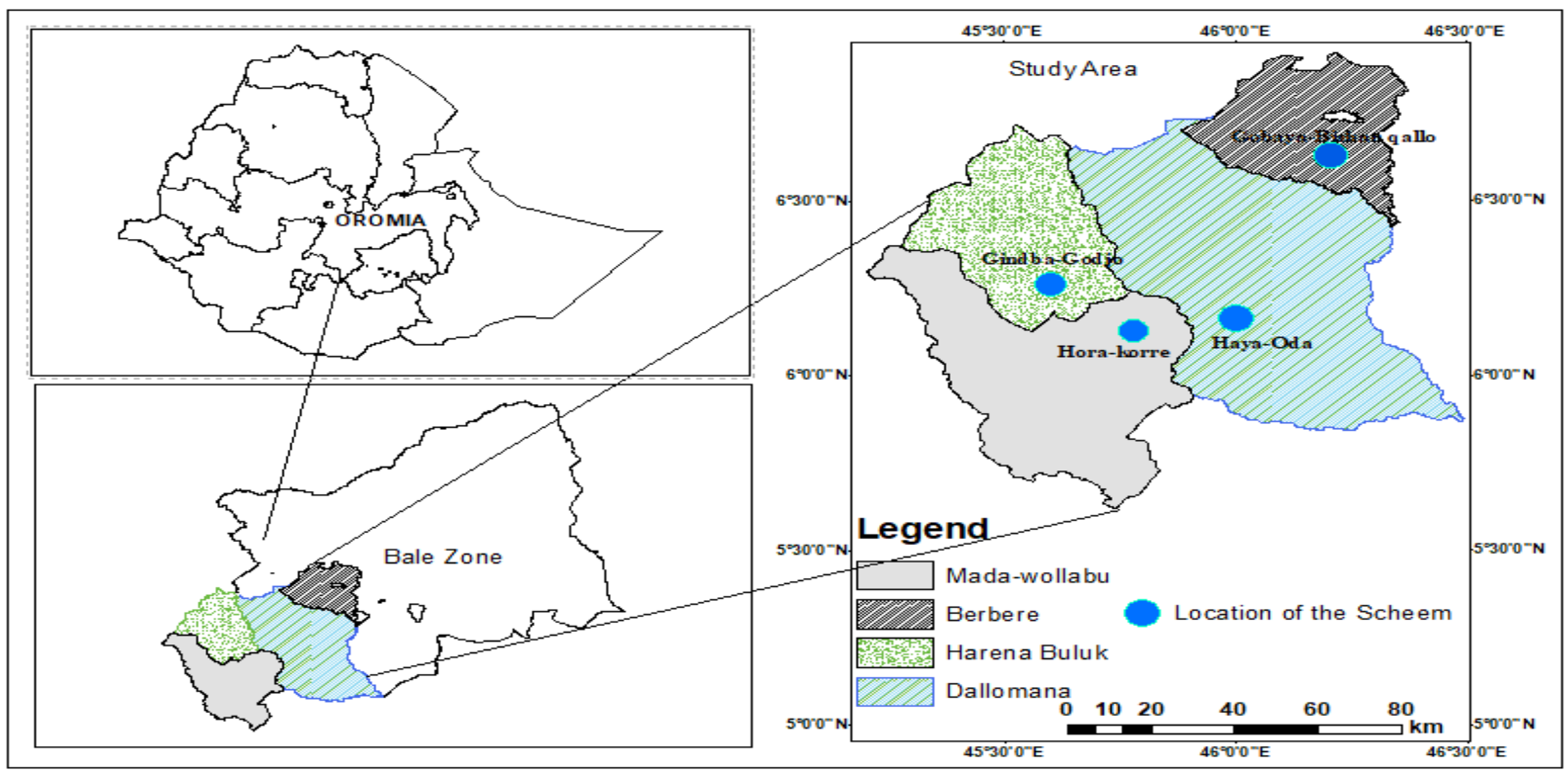

Fig.1 Map of the study area 


\subsection{FRG/FREG establishment}

Farmers research group (FRG) approach was employed in which none FRG farmers (follow farmers) and concerned stakeholders were encouraged to participate in technology demonstration and promotion process. Accordingly, Two FRG in every selected scheme was established from 20 members. During FRG establishment all categories of gender was considered (i.e. adult men, adult women, young men and young female). Selection of farmers to be held in FRG considered farmers' willingness to be held as member, good history of compatibility with groups, genuineness and commitment to share innovations to other farmers.

\subsection{Trial Farmer and Site selection}

Two interested hosting farmers from each FRG were selected for the execution of the demonstration and promotion activity. The target hosting farmers were one who operates on land holdings of less than 0.5 ha in lowlands with potential for irrigation and about 1 ha in the adjacent watersheds. Selection of trial/hosting farmers was carried by discussing with the FRG members and PASDIP-II district focal person accordingly, the project was directly implemented on four farmers in each scheme and total sixteen 16 farmers' field for demonstration whereas the remaining FRG members were attend the implementation of the activity from sucker multiplication to variety demonstration and selection. Each farmer's field was considered as replication of the trial. Farmer selection were based on their representativeness for FRG members, access of irrigation, willingness to manage and allocate field trial for the activity with collaboration of PASDIP-II district focal person.

A total of four improved banana varieties namely Giant Cavendish, Dwarf Cavendish, Poyo and Grand Nain banana variety were evaluated. Sixteen suckers of each improved variety and local banana were planted on single plot basis by using square planting method to make a unit plot area in spacing of $2.5 \mathrm{~m}$ between rows and $2.5 \mathrm{~m}$ between plants within a row making a gross plot area of $400 \mathrm{~m}^{2}$. A total of 64 suckers of improved banana varieties were planted on each farmer's field in randomized complete block design with four replications (Table 1).

Table 1: Summaries of participants and materials used for the demonstration.

\begin{tabular}{lllllll}
\hline District & $\begin{array}{l}\text { Irrigation } \\
\text { Scheme }\end{array}$ & $\begin{array}{l}\text { FRGs } \\
\text { formed }\end{array}$ & $\begin{array}{l}\text { Number } \\
\text { of FRGs } \\
\text { Members }\end{array}$ & $\begin{array}{l}\text { Number of } \\
\text { Trial } \\
\text { site/Farmers }\end{array}$ & $\begin{array}{l}\text { Suckers } \\
\text { distributed/Trial } \\
\text { site }\end{array}$ & Varieties \\
\hline Har/Buluk & $\begin{array}{l}\text { Gindiba- } \\
\text { Gidjo }\end{array}$ & 2 & 20 & 4 & 256 & $16($ each \\
vad/Wolabu & Hora-Korre & 2 & 20 & 4 & 256 & ', \\
Berbere & $\begin{array}{l}\text { G/Bishanqallo }) \\
\text { Dallomanana }\end{array}$ & 2 & 20 & 4 & 256 & ' \\
\hline Total & 4 & 2 & 20 & 4 & 256 & 4 \\
\hline
\end{tabular}

\subsection{Methods of technology promotion in the study area}

Here the main technologies focused by research team were new banana cultivar, with a backet of manure (10 $\mathrm{kg} /$ sucker pit) and irrigation water management. Farmers research groups (FRGs) members and other follower farmers were encouraged to participate on different extension events organized at each site. These were the mechanisms used to enhance farmer-to-farmer learning and information exchange through trainings, field visits/tours, field days, etc. Training was given for farmers and experts (DAs and SMS) before, mid and at the end of the demonstration process in order to build knowledge and skills of the participants toward extension of the technology used. Similarly, mini-field days were organized at representative sites during variety evaluation and selection time to enhance the active participation of farmers in variety selection process.

\subsection{Irrigation water management}

Basin irrigation method was used to irrigate all banana cultivars. Water application depth, irrigation scheduling and other agronomic crop management were carried out depending on farmers' experience.

\subsection{Data collection and analysis}

Yield data and farmers' preference to the varietal traits were collected using field observation, key informant interview and focus group discussion (FGD) methods of data collection. Total number of farmers participated on training, field visits and mini field days were recorded by gender disaggregation. Yield data were analyzed using SAS Software version 9.1 (SAS 2004) while farmers' preference to varietal attributes were identified and ranked using pair wise and simple matrix ranking methods.

\section{Results and discussion}

\subsection{Yield and yield component}

Four improved banana cultivars were evaluated and demonstrated for promotion at Bale Lowland small-Scale Irrigation Scheme as indicated in Table 2. As indicated in the tables there were mean yield and yield component 
differences between varieties. Analysis of variance revealed that number of finger per bunch was significantly different at 5\% level of significance due to variety. Accordingly, the highest number of finger per bunch (142) was recorded for Giant Cavendish followed by Dwarf Cavendish (141) and then Grand Nain (135) varieties whereas the minimum number of finger per bunch (101) was recorded on Poyo variety. On the other hand, the average length of randomly sampled fingers showed that the longest finger $(16.54 \mathrm{~cm})$ was obtained from Giant Cavendish variety whereas the shortest finger length $(10.36 \mathrm{~cm})$ was recorded for poyo variety.

Average weight of finger of banana was also determined and showed significant variation $(\mathrm{P}<0.05)$ among the varieties. Accordingly, the heaviest finger $(0.30 \mathrm{~kg})$ was obtained from Dwarf Cavendish variety whereas the lowest weight of finger $(0.14 \mathrm{~kg})$ was recorded for Poyo variety. Likewise, average weight of bunch per plant was also determined. The maximum weight of bunch per plant was recorded for Dwarf Cavendish variety followed by Giant Cavendish and Grand Nain. However, the minimum average weight of bunch per plant was obtained from Poyo variety. The average yield of banana has also determined for variation between verities and there was significant $(\mathrm{p}<0.05)$ difference among the mean of varieties. Accordingly, maximum yield was recorded from Dwarf Cavendish (17.66 tonha ${ }^{-1}$ ) followed by Giant Cavendish (16.73 ton ha ${ }^{-1}$ ) and Grand Nain (15.49 ton ha-1) whereas the lowest yield was obtained from Poyo (10.42) variety. Dwarf Cavendish, Giant Cavendish and Grand Nain banana varieties has recorded $40.99 \%, 37.66 \%$ and $32.73 \%$ yield advantage over Poyo variety respectively (Table 2). Similar Research work by Tesfa Binalfew and Mekias Damtew (2015) indicated that the highest fruit yield (20.1 tones ha-1) was obtained by Dwarf Cavendish (AAA) while Kamaramasenge (AAB) was the lowest with a yield of (6.1 tones ha-1). The Cavendish group varieties Grand Naine, Giant Cavendish, William-1 and William-2 were also high yielders with a yield of 18.9, 18.4, 17.4 and 17.1 tones ha-1, respectively, which were on par with dwarf Cavendish.

In addition some difference due to location has seen on biological banana performance as defected on (Table 3). Generally these varieties with high number of fingers per bunch, long finger, maximum weight of finger and maximum average weight of bunch per plant is preferable by farmers interims of yield performance.

Table2. Paired sample t-test of mean of varieties

\begin{tabular}{ccccccccc}
\hline Varieties & $\begin{array}{c}\text { Time to } \\
\text { flowering } \\
\text { (days) }\end{array}$ & $\begin{array}{c}\text { Time to } \\
\text { harvesting } \\
\text { (days) }\end{array}$ & $\begin{array}{c}\text { No- } \\
\text { finger/b } \\
\text { unch }\end{array}$ & $\begin{array}{c}\text { No- } \\
\text { hands/ } \\
\text { bunch }\end{array}$ & $\begin{array}{c}\text { Length } \\
\text { of } \\
\text { finger } \\
\text { (cm) }\end{array}$ & $\begin{array}{c}\text { Avg. } \\
\text { weight of } \\
\text { finger }(\mathbf{k g})\end{array}$ & $\begin{array}{c}\text { Avg. } \\
\text { weight } \\
\text { of bunch } \\
\text { (kg) }\end{array}$ & $\begin{array}{c}\text { Total } \\
\text { yield } \\
\text { (tone/ha) }\end{array}$ \\
\hline $\begin{array}{c}\text { Grand } \\
\text { Nain }\end{array}$ & 330 & $443.75 \mathrm{a}$ & $135.25 \mathrm{a}$ & $8 \mathrm{a}$ & $16.13 \mathrm{a}$ & $0.27 \mathrm{~b}$ & $21.93 \mathrm{~b}$ & $15.49 \mathrm{a}$ \\
$\begin{array}{c}\text { Poyo } \\
\text { Giant }\end{array}$ & 308.75 & $407.5 \mathrm{~b}$ & $101 \mathrm{~b}$ & $4.5 \mathrm{c}$ & $10.36 \mathrm{~b}$ & $0.142 \mathrm{c}$ & $8.470 \mathrm{c}$ & $10.42 \mathrm{~b}$ \\
$\begin{array}{c}\text { Cavendish } \\
\text { Dwarf }\end{array}$ & 330 & $441 \mathrm{a}$ & $142 \mathrm{a}$ & $6.75 \mathrm{~b}$ & $16.54 \mathrm{a}$ & $0.27 \mathrm{~b}$ & $23.33 \mathrm{~b}$ & $16.73 \mathrm{a}$ \\
Cavendish & 327.5 & $417.5 \mathrm{~b}$ & $140.75 \mathrm{a}$ & $6.75 \mathrm{~b}$ & $16.06 \mathrm{a}$ & $0.30 \mathrm{a}$ & $25.5 \mathrm{a}$ & $17.66 \mathrm{a}$ \\
\hline $\begin{array}{c}\text { Mean } \\
\text { CV }\end{array}$ & 324.06 & 427.43 & 129.75 & 6.5 & 14.77 & 0.246 & 19.82 & 15.08 \\
\begin{tabular}{c} 
LSD $(0.05)$ \\
\hline
\end{tabular} & 5.83 & 3.05 & 6.96 & 11.32 & 6.61 & 6.15 & 5.56 & 15.32 \\
\hline
\end{tabular}

NB: $*=$ Significant, $* *=$ highly significant

Table 3. Dessert banana cultivars performance biological parameters at harvesting stages, average per sites.

\begin{tabular}{|c|c|c|c|c|c|c|c|c|c|}
\hline Varieties & Site & $\begin{array}{l}\text { Time } \\
\text { to } \\
\text { flower } \\
\text { ing } \\
\text { (days) } \\
\end{array}$ & $\begin{array}{l}\text { Time } \\
\text { to } \\
\text { harve } \\
\text { sting } \\
\text { (days) }\end{array}$ & $\begin{array}{c}\text { No- } \\
\text { finger/bu } \\
\text { nch }\end{array}$ & $\begin{array}{l}\text { No- } \\
\text { hands/ } \\
\text { bunch }\end{array}$ & $\begin{array}{c}\text { Length } \\
\text { of } \\
\text { finger } \\
\text { (cm) }\end{array}$ & $\begin{array}{c}\text { Avg. } \\
\text { weight } \\
\text { of } \\
\text { finger } \\
\text { (kg) }\end{array}$ & $\begin{array}{c}\text { Avg. } \\
\text { weight } \\
\text { of } \\
\text { bunch } \\
\text { (kg) }\end{array}$ & $\begin{array}{c}\text { Total } \\
\text { yield } \\
\text { (Qt/ha) }\end{array}$ \\
\hline \multirow[t]{4}{*}{$\begin{array}{l}\text { Grand } \\
\text { Nain }\end{array}$} & $\begin{array}{l}\text { Gindi } \\
\text { ba- } \\
\text { Gidjo }\end{array}$ & 300 & 420 & 147 & 8 & 17.83 & 0.27 & 22.16 & 169.64 \\
\hline & $\begin{array}{l}\text { Hora- } \\
\text { Korre }\end{array}$ & 320 & 440 & 142 & 9 & 16.30 & 0.29 & 22.20 & 170.80 \\
\hline & $\begin{array}{l}\text { G/Bis } \\
\text { hanqal } \\
\text { lo }\end{array}$ & 340 & 455 & 123 & 7 & 14.90 & 0.25 & 20.23 & 132.00 \\
\hline & $\begin{array}{l}\text { Haya- } \\
\text { Oda }\end{array}$ & 360 & 460 & 129 & 8 & 15.50 & 0.27 & 23.14 & 147.22 \\
\hline Mean & & 330 & 443 & 135 & 8 & 16.13 & 0.27 & 21.93 & 154.92 \\
\hline
\end{tabular}




\begin{tabular}{|c|c|c|c|c|c|c|c|c|c|}
\hline Varieties & Site & $\begin{array}{l}\text { Time } \\
\text { to } \\
\text { flower } \\
\text { ing } \\
\text { (days) }\end{array}$ & $\begin{array}{l}\text { Time } \\
\text { to } \\
\text { harve } \\
\text { sting } \\
\text { (days) }\end{array}$ & $\begin{array}{c}\text { No- } \\
\text { finger/bu } \\
\text { nch }\end{array}$ & $\begin{array}{l}\text { No- } \\
\text { hands/ } \\
\text { bunch }\end{array}$ & $\begin{array}{l}\text { Length } \\
\text { of } \\
\text { finger } \\
\text { (cm) }\end{array}$ & $\begin{array}{c}\text { Avg. } \\
\text { weight } \\
\text { of } \\
\text { finger } \\
\text { (kg) }\end{array}$ & $\begin{array}{l}\text { Avg. } \\
\text { weight } \\
\text { of } \\
\text { bunch } \\
\text { (kg) }\end{array}$ & $\begin{array}{c}\text { Total } \\
\text { yield } \\
\text { (Qt/ha) }\end{array}$ \\
\hline \multirow[t]{4}{*}{ Рoyo } & $\begin{array}{l}\text { Gindi } \\
\text { ba- } \\
\text { Gidjo }\end{array}$ & 310 & 405 & 105 & 5 & 10.17 & 0.15 & 8.46 & 103.84 \\
\hline & $\begin{array}{l}\text { Hora- } \\
\text { Korre }\end{array}$ & 305 & 410 & 109 & 5 & 11.00 & 0.13 & 9.23 & 112.25 \\
\hline & $\begin{array}{l}\mathrm{G} / \mathrm{Bis} \\
\text { hanqal } \\
\text { lo }\end{array}$ & 310 & 415 & 95 & 4 & 10.16 & 0.16 & 7.93 & 97.22 \\
\hline & $\begin{array}{l}\text { Haya- } \\
\text { Oda }\end{array}$ & 310 & 400 & 95 & 4 & 10.12 & 0.13 & 8.26 & 103.41 \\
\hline Mean & & 308 & 407 & 101 & 5 & 10.36 & 0.143 & 8.47 & 104.18 \\
\hline \multirow[t]{4}{*}{$\begin{array}{l}\text { Giant } \\
\text { Cavendish }\end{array}$} & $\begin{array}{l}\text { Gindi } \\
\text { ba- } \\
\text { Gidjo }\end{array}$ & 300 & 425 & 150 & 7 & 18.38 & 0.27 & 24.37 & 197.78 \\
\hline & $\begin{array}{l}\text { Hora- } \\
\text { Korre }\end{array}$ & 320 & 437 & 152 & 8 & 16.83 & 0.27 & 24.50 & 186.45 \\
\hline & $\begin{array}{l}\text { G/Bis } \\
\text { hanqal } \\
\text { lo }\end{array}$ & 340 & 452 & 130 & 6 & 15.89 & 0.25 & 21.25 & 142.00 \\
\hline & $\begin{array}{l}\text { Haya- } \\
\text { Oda }\end{array}$ & 360 & 450 & 136 & 6 & 15.06 & 0.29 & 23.20 & 143.05 \\
\hline Mean & & 330 & 441 & 142 & 7 & 16.54 & 0.27 & 23.33 & 167.32 \\
\hline \multirow[t]{4}{*}{$\begin{array}{l}\text { Dwarf } \\
\text { Cavendish }\end{array}$} & $\begin{array}{l}\text { Gindi } \\
\text { ba- } \\
\text { Gidjo }\end{array}$ & 320 & 400 & 148 & 7 & 16.04 & 0.30 & 26.60 & 206.77 \\
\hline & $\begin{array}{l}\text { Hora- } \\
\text { Korre }\end{array}$ & 320 & 420 & 138 & 7 & 16.05 & 0.29 & 26.00 & 198.00 \\
\hline & $\begin{array}{l}\text { G/Bis } \\
\text { hanqal } \\
\text { lo }\end{array}$ & 340 & 420 & 134 & 7 & 16.09 & 0.32 & 24.82 & 154.22 \\
\hline & $\begin{array}{l}\text { Haya- } \\
\text { Oda }\end{array}$ & 330 & 430 & 143 & 6 & 16.07 & 0.31 & 24.78 & 147.56 \\
\hline Mean & & 327 & 418 & 141 & 7 & 16.06 & 0.31 & 25.55 & 176.44 \\
\hline
\end{tabular}

\subsection{Farmer's preference among the varieties}

Consultative researcher-managed on-farm trials were employed and the farmers were allowed to implement the trial under their supervision. Farmers and researchers work together on implementation of trials and evaluation. By combining informal research by farmers with formal on-farm testing procedures, indigenous knowledge and science-based knowledge were mixed to meet farmers' needs. Hence; field day was organized to collect the preference and create awareness of the trial farmers, experts and extension agents. Market preference, fruit sweetness, fruit size and early maturity were criteria's set by participants of selection process among the varieties. The results of the groups toward the improved variety of banana are indicated below (Table 4).

Table 4. . Criteria used on Banana variety selection and participants Feedback $(\mathrm{N}=132)$

\begin{tabular}{lllllllllll}
\hline Banana Cultivars & \multicolumn{3}{c}{ Market preference } & \multicolumn{3}{c}{ Fruit sweetness } & \multicolumn{2}{c}{ Fruit size } & \multicolumn{3}{c}{ Early maturity } & Rank \\
& No & $\%$ & No & $\%$ & No & $\%$ & No & $\%$ & \\
\hline Grand Nain & 62 & 46.9 & 52 & 39.4 & 38 & 28.8 & 25 & 18.9 & $1^{\text {st }}$ \\
Dwarf Cavendish & 30 & 22.3 & 24 & 18.2 & 50 & 37.9 & 32 & 24.3 & $2^{\text {nd }}$ \\
Giant Cavendish & 25 & 18.9 & 25 & 18.9 & 44 & 33.3 & 28 & 21.2 & $3^{\text {rd }}$ \\
Poyo & 15 & 11.4 & 17 & 12.9 & 0 & 0 & 47 & 35.6 & $4^{\text {th }}$ \\
\hline
\end{tabular}

Farmer's feedback results revealed that fruit size of Dwarf Cavendish variety was larger than Giant Cavendish and other varieties which account, $37.9 \%, 33.3 \%, 28.8 \%$ and $0 \%$, respectively. Grand Nain banana variety was ranked as $1^{\text {st }}$ selection among four banana varieties by the farmers depending on different parameters (Table 4). On the other hand; Dwarf Cavendish and Giant Cavendish banana varieties were evaluated and ranked as $2^{\text {nd }}$ and $3^{\text {rd }}$ selection by the farmers compare to poyo varieties on the bases of marketable (market preference) and fruit 
sweetness which accounted $40 \%$ and $36.2 \%$ as well as $22.9 \%$ and $0 \%$ for market preference and $40 \%$ and $36.2 \%$ as well as $22.9 \%$ and $0 \%$ for sweetness respectively. In Gindiba-Godjo scheme, the issue of size has also considered as criteria of selection process, hence the smallest height of Dwarf Cavendish is perceived as excellent feature for low wind damage (steam strength). Generally on this demonstration farmers preferred Grand Nain banana variety due to its market preference, sweetness, medium fruit size and averagely good yield compared to other varieties, even though it has late maturity compared to poyo and dwarf Cavendish varieties (Table 4).

\section{Conclusion and Recommendation}

On-farm evaluation and demonstration of improved bananas under small-scale irrigation scheme of Bale lowland were conducted to evaluate improved varieties of banana and then promote selected verities in the irrigation scheme. The result of the study revealed that Giant Cavendish, Dwarf Cavendish and Grand-Nain varieties have showed advantage over Poyo variety in terms of their number of hands per bunch, number of finger per bunch and weight of finger per bunch. Similarly; from farmer's feedback during demonstration; Grand Nain banana variety was ranked as $1^{\text {st }}$ selection by the farmers on the bases of market preference, sweetness, medium fruit size and averagely good yield compared to other varieties. On the other hand Dwarf Cavendish and Giant Cavendish banana varieties were evaluated and ranked as $2^{\text {nd }}$ and $3^{\text {rd }}$ selection by the farmers compare to poyo variety on the bases of market preference, fruit size and fruit sweetness. Hence; by combining informal research by farmers with formal on-farm testing; Grand Nain, Dwarf Cavendish and Giant Cavendish banana varieties were recommended and ranked as $1^{\text {st }}, 2^{\text {nd }}$ and $3^{\text {rd }}$ selection in the scheme; respectively. Therefore; for further scale out of these selected banana verities with irrigation and a bucket of organic fertilizer (compost/ manure) in Bale low land, can increase production and productivity of banana in the study area and contribute a lot in changing the livelihood of the farming community and availability of suckers for further dissimilation can easily be ensured.

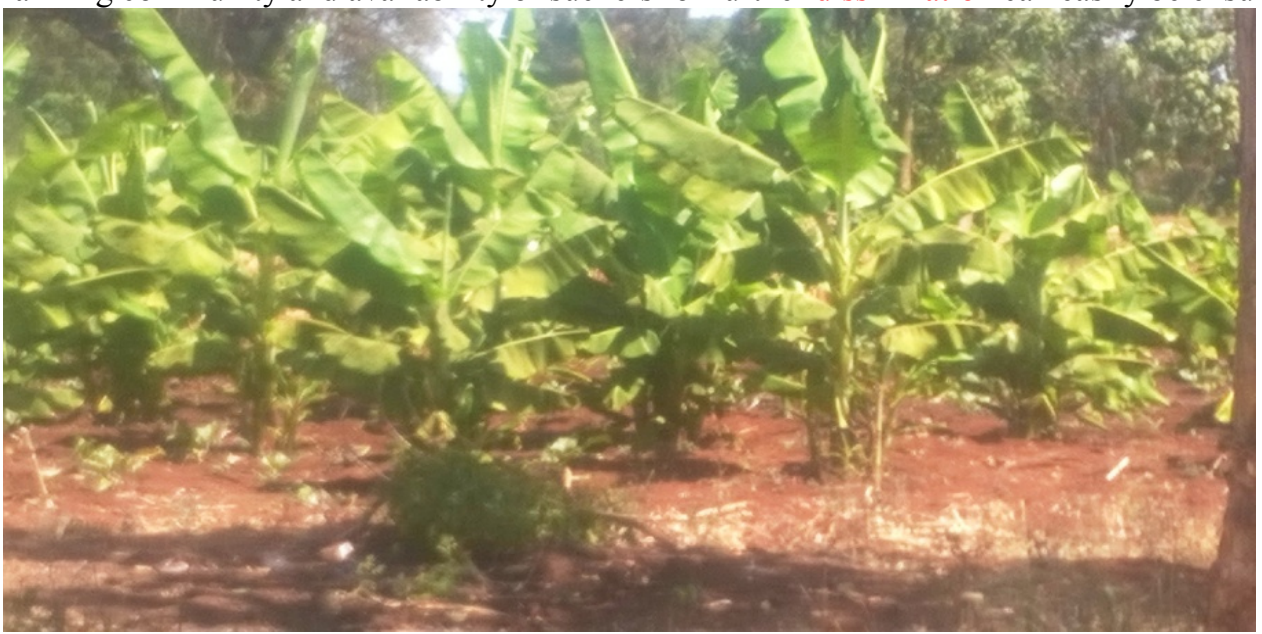

Fig. 2 Transplanted suckers at four months stage of development

\section{References}

Central Statistical Agency (CSA).2016. Agricultural Sample Survey 2015/2016 (2008 E.C.). Report on Area and Production of Major Crops (Private Peasant Holdings, Meher Season). Statistical Bulletin 548, Volume I, Addis Ababa, Ethiopia.

CSA (Central Statistical Agency of Ethiopia).2014. Agricultural Sample Survey. Report on Area and Production of Major Crops. Volume I, VII and VIII. Statistical Bulletin 578. Addis Ababa, Ethiopia

CSA, 2011. Agricultural sample survey 2010/2011 (2003 E.C.). Report on area and production of major crops. Central Statistical Agency of Ethiopia, Addis Ababa, Ethiopia.

Ethiopian Agriculture Research Organization (EARO).1999. Banana production and utilization in Ethiopia.Ethiopian Agriculture Research Organization, Research report No. 35, Addis Ababa.

FAO, 2017. Data: Production Quantity. FAO, Rome Italy. http://www.fao.org/faostat/en/\#data/QC (Accessed on 12 April 2017).

FAOSTAT (Food and Agriculture Organization Statistical Division), 2O12. Overview of World Banana Production and Trade. The World Banana Economy, 1985-2012. FAO Corporate Document Repository. Produced by Economic and Social Development Department. http://faostat3.fao.org/home/index.html\#DOWNLOAD

John H., 1997. Extension Education: Conducting Effective Agricultural Demonstrations, Kentucky Cooperative Extension Service, University of Kentucky College of Agriculture, Lexington, and Kentucky State University, Frankfort

Kamira M, Sivirihauma C, Ntamwira J, Ocimati W, Katungu MG,Bigabwa JB, Vutseme L, Blomme G.,2015. 
Household uses of the banana plant in eastern Democratic Republic of Congo. J. Appl. Biosci. 94:8915-8929. Karamura EB., 1993. The strategic importance of bananas/ plantains in Uganda. In: Gold, C.S. and Gemmill, B. (eds). Biological and Integrated Control of Highland Banana Pests and Diseases in Africa. Proceedings of a research coordination meeting held in Cotonou, Benin, 12-14 November 1991. pp. 384 - 387.

Salvador, A., Arnal, L., Manterde, A. and Cuquerella, J., 2007. Reduction of chilling injury sysptoms in persimmon fruit cv. 'RojoBrillante by 1-MCP, Postharvest Biology and Technology 33:285-281

Silva SO, Alves EJ, Lima MB, Silveira JRS 2002. Bananeira. In:Bruckner, C.H (ed). Melhoramento de FruteirasTropicais.Viçosa:UFV. pp. 101-157.

Tesfa Binalfew and Mekias Damtew, 2015. Evaluation of the Adaptability of Dessert Banana Cultivars at Belese Valley, North Western Ethiopia Melkassa Agricultural Research Centre, Adama, Ethiopia. African Journal of Agricultural Research. 10(30):2995-2999. DOI: 10.5897/AJAR2014.9352 Article Number: 486AD5F54467 ISSN 1991-637X http://www.academicjournals.org/AJAR. 